\title{
World and Latin American congresses on sexually transmitted diseases
}

\author{
Report of the First World Congress and Third Latin American Congress on sexually transmitted diseases, \\ San Juan, Puerto Rico, 15-21 November 1981
}

The First World Congress and the Third Latin American Congress on sexually transmitted diseases were held in San Juan, Puerto Rico, from 15 to 21 November 1981. More than 1400 participants from 50 different countries took part; they and their families and friends filled three resort hotels in Isla Verde.

The idea of the congress had originally been put forward by $\mathrm{Dr}$ Yamil $\mathrm{H}$ Kouri (Puerto Rico), and an organising committee headed by Dr Ronald K St John of the Pan American Health Organisation had been established the previous year. The congress was sponsored by the World Health Organisation, the International Union against the Venereal Diseases and Treponematoses, the Center for Disease Control, the National Institute of Health, the Latin American Union against the Venereal Diseases, and many other national and international agencies.

In his opening address the director of the congress, Dr Yamil Kouri, reminded delegates that the incidence of all the sexually transmitted diseases was increasing throughout the world and the number of diseases that were now known to be spread by this route was much greater than was generally believed. The fact that more than 1400 doctors from over 50 different countries, representing millions of patients all over the world, had come to the congress was an indication of the growing importance of the subject in modern medicine.

The members of the congress were welcomed by Dr N Maldonado, the chancellor of the University of Puerto Rico, the Hon Carlos Romera Barcelo, governor of the Commonwealth of Puerto Rico, Dr J Rivera Dueno, secretary to the Department of Health of the Commonwealth of Puerto Rico, Dr R D Catterall, president of the International Union against the Venereal Diseases and Treponematoses, Dr H Acuna, director of the Pan American Health

Address for reprints: Dr R D Catterall, James Pringle House, Middlesex Hospital Medical School, London W1A 8AA

Accepted for publication 17 January 1982
Organisation, Dr W Foege, director of the Center for Disease Control, and the Hon $\mathbf{R}$ Schweiker, secretary of the Department of Health and Human Services of the Commonwealth of Puerto Rico.

Throughout the four principal days of the congress a number of sessions occurred simultaneously, and covered a wide variety of subjects. The programme contained a chart of all the sessions indicating in which of six possible locations a particular paper was to be presented. This arrangement allowed a large number of papers to be read but it also meant that important papers were often presented at the same time in different locations making it impossible to hear more than a selection of the communications. Some delegates found the programme too complicated and could not find the location at which specific subjects were to be discussed and they became confused and disorientated.

Nevertheless, the level of organisation was very high by international standards and most sessions took place without any difficulties. The speakers usually observed their time limits and the moderators conducted the discussions with firmness and discretion. There were, however, recurrent problems with the loud-speaker systems and with the slide projection services, a defect which is all too familiar and too common at medical and scientific meetings. Although the official language of the congress was English, simultaneous translation services were available at some of the sessions.

The first day was characterised by an excellent research symposium on the pathogenic mechanisms of bacterial sexually transmitted diseases. Dr P F Sparling spoke on gonorrhoea, $\mathrm{Dr} J$ Schachter on chlamydia, Dr R Swenson on group B streptococci, and Dr D Musher on syphilis. These papers set the standards for the whole conference and were listened to by a packed and appreciative audience. Later that day an excellent symposium on herpes simplex virus and cytomegalovirus provoked a lively discussion. Meanwhile, in other locations the efficacy of penicillin treatment of early syphilis in the prevent of neurosyphilis was discussed by Dr Axel Perdrup (Denmark), hepatitis B virus in elections in venereal disease clinic patients क्षy Dr P E Taylor (Canada), and infecti@s caused by penicillinase-producing Neisseria gonorrhoeae in the United States from 1996 to 1981 by Dr H Joffe (United States). iv

Throughout the congress a series of S update workshops, stressing the fundamentals of diagnosis and treatment, werre held in several locations; poster sessions were established and there were panel cussions on a variety of subjects, suchoas herpes, children and STD, legal aspects - of women and STD, and prostitution. The STD update programmes were of a very high standard and provided an excelleht factual background to the research papers which were being presented simultaneou్ㅠㅇㅢ elsewhere.

A whole morning session on chlamye्ष्रia and ureaplasmas provoked much disctussion; simultaneously there was a session $\vec{\delta}$ methods of training for those working wth STDs. The principles, methods, and current training practices in Britain, the USA, Latin America, and Africa were described and a variety of short-term training pgrammes mostly being developed in क्रुe USA were discussed. The methods employed in establishing a model S\&્ङD clinic were described by Dr Yamil Kợri (Puerto Rico).

On the third day of the congres ${ }^{2} a$ morning session was devoted to fhe pathogenic mechanisms of viral SH, which included up-to-date papers on herpes simplex, cytomegalovirus, hepatitis B, and recent developments in the treatment of viral diseases. The session devoted 겅 gonorrhoea was dominated by papers $\delta$ n resistance to penicillin and $\beta$-lactamasseproducing strains of Neisseria gonorrhoede. The session devoted to vaginal chemophophylaxis in the prevention of STD was very disappointing as there were few new factipal data, a dearth of current research, and $\mathrm{an}$ absence of new ideas. Many excellent posfer displays, laboratory demonstrations, 要 audiovisual exhibits were available for 
those who could find them in the maze of rooms in the three congress hotels.

On the fourth day a morning was devoted simultaneously to syphilis and to a general session on STD education. Much interesting research on Treponema pallidum was reported, and for those more interested in education, the objectives, evaluation, and practice of public health education on STDs were discussed at length.

On the last day a major research symposium on STD vaccines, antigenic determinants, and immune responses was attended by a packed auditorium. The situation concerning gonorrhoea was reviewed by $\operatorname{Dr} \mathrm{E}$ Tramont (USA) and group B streptococci by Dr D Kasper. Owing to the illness of Dr W Szmuness his paper on hepatitis B was presented by Dr P $E$ Taylor (Canada). An excellent review of other potential STD vaccines was given by Dr G Schoolnick (USA), and the session ended with a thought-provoking discussion paper on "Perspectives for public health usage of STD vaccines" by Dr K K Holmes (USA).

The formal sessions ended with a special update paper by Dr Jame; Curran (USA) on Kaposi's sarcoma and the reports that the condition had been diagnosed in a number of homosexual men. The cause is unknown and the condition has been fatal in some of the patients.

It was fitting that the Parran Award for outstanding work on venereal diseases was given to Dr James Curran by the president of the American Venereal Diseases Association, and a number of awards were made by the Latin American Union against the Venereal Diseases.

The congress was finally closed with some concluding remarks by the chairmen of the various sections of the executive committee. Dr R St John (USA) announced that the executive committee was now dissolved but a recommendation had been made that a second world congress should be organised in about four to five years' time in view of the great success of the present congress.

Dr R D Catterall (London) thanked all those who had been concerned with the organisation of the congress and had contributed to the great success of the meeting and in particular Dr R St John (USA), who had been the main organiser of the whole congress and was responsible for the detailed planning and smooth running of all the sessions. But the originator of the idea and the man who had really made it all

\section{Book review}

Sexually Transmitted Diseases. By Mohamed Farid, 1981. Ain Shams University Press, Cairo, Egypt. Pp 647. Price not stated.

The author of this large volume is assistant professor of dermatology and venereology. His book has been published by his own University Press in Cairo but nevertheless appears to have been written in the United Arab Emirates, where he is also head of the department of dermatovenereology at the Military Hospital, Abu Dhabi. He has achieved a clear and comprehensive presentation of the sexually transmitted diseases, their problems and management, expressing views which are generally accepted in western countries. This is not surprising as it reflects well the information in the 175 or so world references quoted. In some 30 instances, however, passages or even whole paragraphs, with scant acknowledgement, have been taken verbatim or virtually so from Sexually Transmitted Diseases (C B S Schofield, 3rd ed, Edinburgh: Churchill Livingstone, 1979). Nevertheless, it could be a very useful vehicle to convey current trends in sexually transmitted diseases to physicians in the Middle East.

The chapters are conventionally arranged and cover chlamydial and the various viral infections, with a closing appendix on techniques and normal values of body fluids. There is also a chapter on the mechanism of erection and ejaculation, which devotes some space to priapism and its treatment but curiously makes no mention of im- possible was Dr Yamil Kouri (Puerto Rico). $\stackrel{\Phi}{\overparen{\$}}$ Dr Catterall presented Dr Kouri with an $\stackrel{\mathbb{Q}}{\mathcal{D}}$ engraved wall plaque, commemorating the $\square$. congress, on behalf of all the delegates and participants and congratulated him on the $\vec{F}$ very great success of the first world $\stackrel{?}{?}$ congress on sexually transmitted diseases.

During the course of the congress the International Union against the Venereal $\frac{\bar{\omega}}{\bar{a}}$ Diseases and Treponematoses held two $\mathbb{D}$ executive committee meetings, which were both well attended. The American Venereales Diseases Association also held a meeting. $\vec{O}$

There was an excellent social programmeduring the day time; a reception-cocktail $\vec{\omega}$ party, an evening Rum Swizzle party, a banquet, and big band dance were all highly $\stackrel{\text { ? }}{=}$. successful and well attended.

It was generally agreed that the congress 0 had been an unqualified success and hadi contributed greatly to the understanding of the many problems associated with the $\mathrm{O}$ sexually transmitted diseases. It had also acted as a stimulus to all those working in $\vec{c}$ the field and should be a reminder to politicians and health care administrators that $\mathbb{1}$ this problem will require increased resources $\overrightarrow{0}$ both now and in the future.

$R$ D Catterall ${ }^{N}$ (president, IUVDT)

potence. Two short historical sections on syphilis and gonorrhoea list many famous people who are stated to have had these diseases.

The printing style is that of a doublespaced typewriter with only about half the usual number of lines per page, whicho results in a larger volume than usual. There N are eight pages of colour pictures and a fewN diagrams. With the reservations already ${ }_{\sigma}$ expressed there is much good sense in its contents, which read well with a commend-을 able lack of embellishment. There are, however, some 60 noted errata (nearly all of? spelling), some of which might have passed unnoticed had a slip detailing them not been supplied with the book.

$R R$ Willcox 